University of Nebraska - Lincoln

DigitalCommons@University of Nebraska - Lincoln

Genomic and transcriptomic studies in Mycobacterium avium subspecies paratuberculosis

J. P. Bannantine

Adel M. Talaat

Follow this and additional works at: https://digitalcommons.unl.edu/usdaarsfacpub

Part of the Agriculture Commons

This Article is brought to you for free and open access by the U.S. Department of Agriculture: Agricultural Research Service, Lincoln, Nebraska at DigitalCommons@University of Nebraska - Lincoln. It has been accepted for inclusion in Publications from USDA-ARS / UNL Faculty by an authorized administrator of DigitalCommons@University of Nebraska - Lincoln. 


\title{
Genomic and transcriptomic studies in Mycobacterium avium subspecies paratuberculosis
}

\author{
John P. Bannantine ${ }^{\mathrm{a}, *}$, Adel M. Talaat ${ }^{\mathrm{b}, \mathrm{c}}$ \\ a National Animal Disease Center, USDA - Agricultural Research Service, 2300 North Dayton Avenue, Ames, IA, USA \\ b Department of Food Hygiene, Cairo University, Egypt \\ c Laboratory of Bacterial Genomics, Department of Pathobiological Sciences, University of Wisconsin, Madison, WI, USA
}

\section{A R T I C L E I N F O}

\section{Keywords:}

Mycobacterium paratuberculosis

Johne's disease

Transcriptomics

Microarray

Genomics

\begin{abstract}
A B S T R A C T
Microarray technology is an important tool in functional genomic research. It has enabled a deeper analysis of genomic diversity among bacteria belonging to the Mycobacterium avium complex (MAC). In addition, the expression of thousands of genes can be studied simultaneously in a single experiment. With the complete genome sequence of a bovine isolate of M. avium subspecies paratuberculosis, and the independent construction of DNA microarrays in our laboratories, transcriptomic studies for this veterinary pathogen are now possible. Furthermore, the bovine genome sequence project is completed and bovine arrays have been developed to examine host responses to infection with $M$. avium subsp. paratuberculosis. Collectively, genomic and transcriptomic data has yielded novel insights surrounding the genetic regulation and biology of Johne's disease.
\end{abstract}

Published by Elsevier B.V.

\section{Introduction}

Important and foundational research that includes genome sequencing and microarray design has been completed for the veterinary pathogen Mycobacterium avium subspecies paratuberculosis (MAP). Subsequent studies using this foundation have led to a better understanding of the genomic diversity and biology of this bacterium. Much of the focus on MAP is warranted as it causes a disease of considerable economic impact to dairy industries worldwide. It is estimated that annual losses to the U.S. dairy industry from Johne's disease exceed $\$ 220$ million USD (Ott et al., 1999). Specifically, lower lactation performance and early culling from the herd are the main reasons for such losses (Raizman et al., 2009). Johne's disease presents as a granulomatous inflammation of the intestinal tissue and regional lymph nodes due to a massive influx of monocytes and macrophages. This inflammation effectively prevents

\footnotetext{
* Corresponding author. Tel.: +1 515663 7340; fax: +1 5156637458 E-mail address: john.bannantine@ars.usda.gov (J.P. Bannantine).
}

absorption of nutrients, and therefore cattle in the later stages of disease show significant weight loss and diarrhea. However, the infection is chronic and it takes years to observe clinical signs. Transmission of the organism is via young calves feeding on milk contaminated with MAP. The bacterium is also shed in the feces, therefore fecal-oral route is another mode of transmission.

The field of functional genomics has revolutionized our understanding of the process of transcription, as it couples the power of complete genome sequencing with the miniaturization of PCR products or oligonucleotide arrays, allowing the generation of information about the total cell transcriptional responses in defined conditions. In the genus Mycobacterium alone, metabolic studies (Kendall et al., 2007; Micklinghoff et al., 2009; Talaat et al., 2007), virulence gene expression (Abomoelak et al., 2009; Agarwal et al., 2007), pseudogene transcription (Williams et al., 2009), host response to infection (Beisiegel et al., 2009), transcriptional regulators and the genes they affect (Fontan et al., 2009; Kendall et al., 2007; Ward et al., 2008) have all been advanced using microarray technology. The explosive growth of publications using microarrays has prompted 
development of the MIAME guidelines (Brazma et al., 2001) to ensure minimal reporting standards for microarray data, and subsequent technological advances in array production allowed for more sophisticated techniques like ChIP-on-chip technologies (chromatin immunoprecipitation followed by DNA microarray) for the genome-wide detection of binding sites for DNA-binding proteins (Sala et al., 2009). Recently, high-density tiling arrays with short oligonucleotide overlaps have already allowed a more detailed study of transcription in MAP, M. leprae, Caulobacter crescentus, Listeria monocytogenes and Bacillus subtilis (McGrath et al., 2007; Rasmussen et al., 2009; Akama et al., 2009; Toledo-Arana et al., 2009; Wu et al., 2006, 2007). We now know that the microbial transcriptome is much more complicated than previously thought, and includes long antisense RNAs and many more noncoding RNAs than identified previously (Rasmussen et al., 2009; ToledoArana et al., 2009). Tiling arrays advance transcriptomics because they are not bound by the annotation errors in genomics. In fact, they can be used to identify transcriptionally active genes missed by annotation as we discovered in our laboratories (unpublished data). The only technology not adopted yet for Johne's disease is ChIP-on-chip experiments. Nonetheless, important insights into Johne's disease have been gained from both the host and pathogen perspectives using microarrays.

\section{MAP genomic diversity}

MAP is a member of the Mycobacterium avium complex (MAC). Other members of the MAC group include M. avium subspecies avium (MAA), M. avium subspecies silvaticum (MAS), M. avium subsp. hominsuis (MAH) and a second species $M$. intracellulare $(M I)$. Cattle can be infected systemically with $M A A$ and $M A H$, but humans are infected preferentially with $M A H$. All members of the MAC are highly genetically similar, although the small distinctions between MAA and MI are now well established (Boddinghaus et al., 1990; De Smet et al., 1996; Feizabadi et al., 1997; Thorel et al., 2001). The genome sequences available for members in the MAC group are only MAP K-10 and $M A H$ strain 104 . These two genomes clearly demonstrate the close genetic similarity between these subspecies and furthermore, DNA-DNA hybridization studies have long ago shown a strong genetic similarity between MAP and MAA (Hurley et al., 1989; Saxegaard et al., 1988; Yoshimura and Graham, 1988). More recently, a greater than $98 \%$ nucleotide identity was shown to exist when comparing the majority of the MAP and MAH genomes to each other (Bannantine et al., 2003). Preliminary data suggested that MAP and MAS may be even more similar than $M A P$ and $M A H$ (Paustian et al., 2005). However, more recent genotyping data now shows that $M A H$ and $M A S$ are closer to each other than they are to MAP (Turenne et al., 2008). This close genetic relatedness does not explain why members of the MAC group are so phenotypically different.

Genetic diversity among MAP isolates has been the predominant theme in published MAP genomic studies during 2003 to the present. From repetitive DNA sequences (Amonsin et al., 2004; Bull et al., 2003) to amplified fragment length polymorphism (AFLP) and pulsed-field gel electrophoresis (PFGE) analysis (de Juan et al., 2005; O'Shea et al., 2004), differences on the MAP chromosome have been identified and utilized for discriminatory subtyping of isolates. Most of these studies have used the genome sequence of MAP to aid in the identification of genetic regions of variability (Amonsin et al., 2004; Overduin et al., 2004; Paustian et al., 2005; Semret et al., 2004). Techniques that both reveal genetic diversity and can be used to discriminate among MAC isolates include short sequence repeat analysis (Amonsin et al., 2004), variable number tandem repeat analysis (Bull et al., 2003; Overduin et al., 2004), PFGE (de Juan et al., 2005), AFLP (O'Shea et al., 2004) and representational difference analysis (RDA) (Dohmann et al., 2003). All were used to distinguish between MAP and MAH. In one study, optical mapping was used to examine genomic synteny among MAP isolates and showed a great deal of conserved genomic organization (Wu et al., 2009).

Prior to the development of a MAP microarray, some regions of the $M A P$ genome had been discovered that are not present in $M A H$. Sheridan and coworkers (Sheridan et al., 2003) examined the GS element of MAP which was previously found using RDA and is reported absent in $M$. avium subsp. avium (Tizard et al., 1998). This 6500-bp region was analyzed in silico using bioinformatics tools, which predicted that coding sequences are involved in GDP-fucose biosynthesis and modification of the oligosaccharide moiety of GPL. Stratmann et al. (2004) also used the RDA technique to find a novel 7-kb ABC-transporter operon located within a 38 -kb segment that is flanked by an insertion sequence. Also located on this $38-\mathrm{kb}$ island are several gene clusters thought to be involved in iron uptake. These investigators went further by demonstrating the location and expression of two coding sequences in the ABC transporter operon to support their in silico findings. They found that both MptC and MptD were surface located on the MAP bacilli. They concluded that this is the first pathogenicity island discovered in MAP. Despite these significant studies, the presence or absence of genes at a whole genome level still remained to be defined.

\section{A key tool: the DNA microarray}

It was against this background that microarray-based genomic studies were initiated. The goal was to better define genes that were present or missing when comparing genomic DNA from two strains or isolates by competitive hybridization to a microarray. These comparisons might reveal differences that could yield clues to host range or phenotype. For example, it is well known that MAP requires exogenous mycobactin $\mathrm{J}$ in the culture media for growth whereas $M A A$ and $M A H$ do not. It has been observed that the $m b t A$ gene in the mycobactin biosynthesis operon is truncated in MAP compared to MAH suggesting that this may be a reason for the mycobactin J requirement ( $\mathrm{Li}$ et al., 2005).

The first MAP microarray consisted of spotted PCR products based on predicted coding sequences in the K-10 genome (Li et al., 2005). This library of PCR products representing MAP coding sequences was constructed with primers designed by Primer3 software (Rozen and Skaletsky, 2000) to amplify fragments of 500 bp from each 


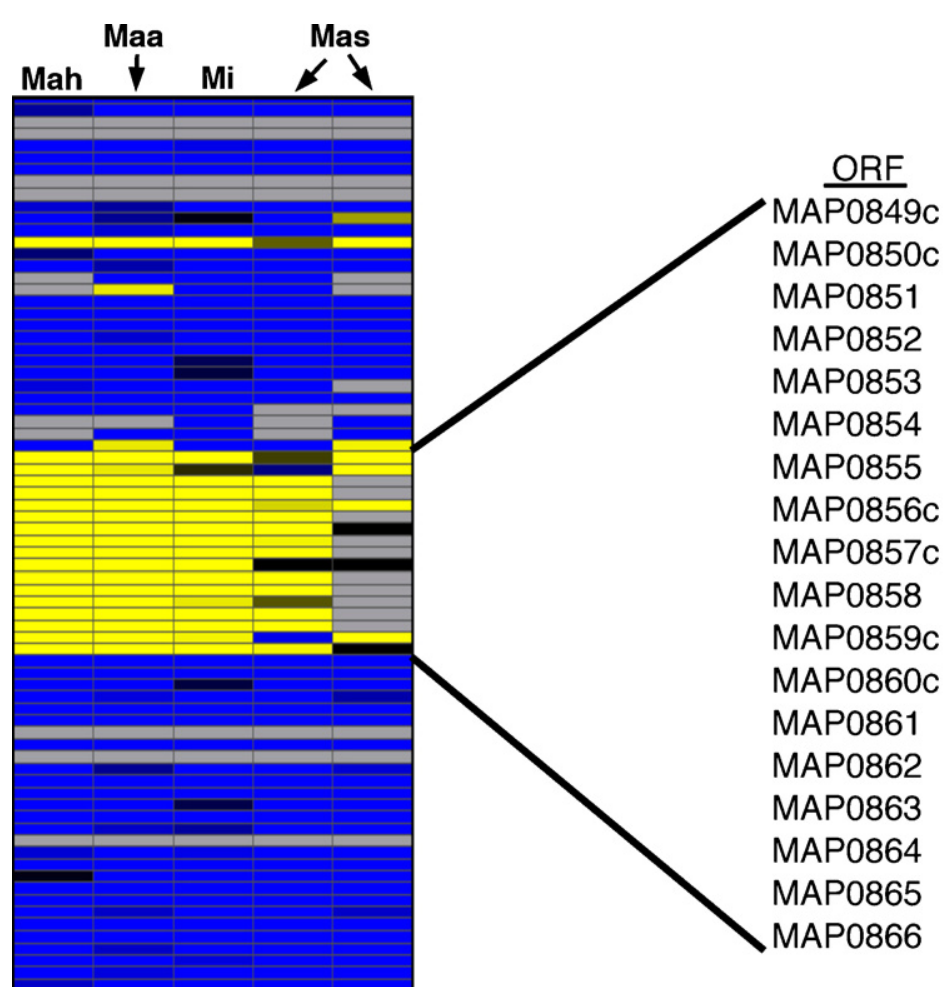

$-0.5$

Estimated probability present (EPP)

Description
IS1311
similar to ISmav2
no hits
no hits
hypothetical protein
Putative rep protein
no hits
no hits
hypothetical protein
no hits
Mycobacterium phage L5
no hits
no hits
no hits
no hits
no hits
Hypothetical $30.9 \mathrm{kDa}$ protein
integrase

0.5

Fig. 1. Comparative genomic hybridization analysis of MAC species. Shown is a clustergram displaying hybridization signals generated from genomic DNA hybridizations of different mycobacterial isolates. Each column in the clustergram represents a single microarray profile from the species indicated at the top. Only the hybridization signals from a region encompassing gene identifiers MAP0821 to MAP0896 are shown. The yellow-to-blue color bar represents low to high log ratios of the hybridization signals generated from each genome relative to that of $M A P \mathrm{~K}-10$. The genes shown in yellow, indicating a low probability of being present in those genomes, corresponds to LSP4 (Semret et al., 2005), which is an insertion present only in MAP. MAH=M. avium subspecies hominissuis, $M A A=M$. avium subspecies avium, $M I=M$. intracellulare, $M A S=M$. avium subspecies silvaticum. (For interpretation of the references to colour in this figure legend, the reader is referred to the web version of the article.)

ORF using purified genomic DNA as template. The array was built with 4110 PCR products representing $95 \%$ of the genome. It was used in DNA hybridization experiments to examine genomic diversity among species (Paustian et al., 2005). Using the array of spotted PCR products, some differences in MAC members became evident. Through this approach, 3 defined segments, comprising 24 genes were missing in the MAP sheep strain, Telford 9.2 when compared to the bovine strain K-10 (Marsh et al., 2006). One identified region of difference (RD) is shown in Fig. 1. These genomic differences may account for the host specificity observed in sheep strains.

Because only $95 \%$ of the genes could be amplified by PCR from this GC-rich bacterium, an oligonucleotide array was designed and built. Every predicted open reading frame in the MAP strain K-10 genome is represented on this array. One 70-mer was designed for each gene with a total length of less than $4000 \mathrm{bp}$, while longer genes were split in half and one 70-mer oligo was designed for each half. This array had the added feature of containing $M A H$ sequences that were less than $30 \%$ identical to MAP genes. Additional details of this microarray design can be found elsewhere (Paustian et al., 2008). Two additional oligo arrays were built using $M A H$ strain 104 sequence data (Semret et al., 2004; Wu et al., 2006). One of these arrays contained oligonucleotide probes 70 nucleotides in length (Semret et al., 2004) while the other consisted of tiled oligonucleotides where each gene was represented by 14 pairs of probes (Wu et al., 2006). The $M A H$ subspecies is similar enough that these arrays were successfully used to examine genomic differences between MAP and other members of the MAC. A second-generation array was constructed that contained both subspecies paratuberculosis and hominissuis. This microarray contains 60-mer oligonucleotide probes that represent $100 \%$ of the annotated genes in both genomes, yet uses only 5744 probes in the final set (Castellanos et al., 2009).

To better understand the host response to infection with MAP, a bovine microarray was constructed in Paul Coussens' lab at Michigan State University. The first generation bovine cDNA array used in studies on Johne's disease was a bovine total leukocyte array, termed BOTL-2, that consisted of 721 bovine expressed sequence tags (ESTs) and amplicons representing known genes (Coussens et al., 2002). The known genes included those encoding cytokines IL-1, IL-4, IL-5, IL-6, IL-10, IL-12, TNF- $\alpha$ and IFN- $\gamma$. This array continued to evolve into the BOTL-3, which had 709 ESTs and 345 amplicons representing known genes (Coussens 
et al., 2003) and finally, the BOTL-5, which contained 750 ESTs and 750 known gene amplicons (Murphy et al., 2006; Skovgaard et al., 2006). As described below, unique insights on the bovine immune response were obtained using the BOTL array. The only other host array used in MAP studies is the mouse array for examining response to MAP and MAA infections of murine macrophages. The investigators found a significant decrease in genes that promote inflammatory responses for MAP, but not MAA (Basler et al., 2008).

\section{Genomic diversity revisited}

All of these $M$. avium-based arrays were initially built to examine genomic diversity and as such they were hybridized with genomic DNA to determine presence or absence of genes. A total of 24 and 18 genomic islands were identified belonging to $M A H$ and $M A P$, respectively (Wu et al., 2006) suggesting the mosaic nature of genomes among MAC strains (Alexander et al., 2009). Interestingly, large regions of genomic inversions were found among $M A P$ and $M A H$ strains (Fig. 2; Wu et al., 2006), another indication of the presence of a common ancestor between members of the MAC group.

With the array constructed, genomic diversity and evolution of the MAC complex organisms began to crystallize into focus. The major genomic differences were identified as insertions or deletions among MAC strains. Large sequence polymorphisms were described and it was suggested that diagnostic sequences might be contained within these regions. A total of 6 genomic insertions specific to MAP comprise $125 \mathrm{~kb}$, two of which are putative prophages (Alexander et al., 2009). In contrast, one 10-kb deletion (LSP8) is consistent in all MAP strains. Analysis of the LSP regions as insertions or deletions led to the proposal of a biphasic evolution of MAP (Alexander et al., 2009). Added to these data was an extensive multilocus sequencing study that suggested $M A H$ is the ancestor strain from which MAP and MAA independently evolved (Turenne et al., 2008). Finally, it appears that MAP itself is genetically homogenous with primary differences observed between cattle and sheep strains. Therefore, genome sequencing of a sheep isolate is recommended to complete this knowledge gap. We are currently sequencing an ovine isolate from a Suffolk sheep in the United States. This genome has recently been assembled into a single scaffold and closing remaining gaps will be done quickly. This genome will comprehensively detail all the differences between sheep and cattle isolates of MAP.

\section{Defining the transcriptome in $M$. avium subsp. paratuberculosis}

Surprisingly, despite the number of studies using the $M A P$ or $M A P-M A H$ microarray to identify genomic differences through DNA hybridizations, very few investigators have advanced into transcriptomic experiments using these same arrays. This is disappointing because animal models for Johne's disease need further development (Hines et al., 2007) and transcriptomic studies are expected to reveal which model host might best simulate Johne's disease. Furthermore, because there are immunologically defined stages of Johne's disease, infected asymptomatic, subclinical and clinical, transcriptomic studies might reveal what triggers the progression of the disease into the next stage. Currently, identification of MAP gene expression levels within cultured macrophages, such as monocyte-derived macrophages, is a good way to improve understanding of MAP pathogenesis. Although the microarray and RT-PCR are the primary methods used in such studies, transcripts of MAP infected bovine monocytederived macrophages have also been identified by the selective capture of transcribed sequences (SCOTS) method (Zhu et al., 2008). In addition, differential display PCR was used to identify gene expression differences in sheep tissues (Zhong et al., 2009).

There are only a few published studies that use the microarray to examine MAP transcriptional responses in defined conditions. These include the response of MAP exposed to artificial stress conditions such as low $\mathrm{pH}$, heat and oxidative stress (Wu et al., 2007), exposure to the rhodanine agent D157070 (Bull et al., 2009), iron dependency (Janagama et al., 2009) as well as natural stress conditions (in fecal samples) (Wu et al., 2007). Surprisingly, a large number of genes were activated following exposure to low $\mathrm{pH}(n=597)$ indicating the vigorous MAP response to acidic conditions encountered during passage through the calf digestive system or inside phagosomes of host macrophages. In addition, MAP transcriptomes under heat shock or oxidative stress were very similar to those of $M$. tuberculosis (Wu et al., 2007) suggesting common responsive pathways for these intracellular pathogens.

Moreover, D157070 was shown to kill both actively growing and latent MAP. Transcriptome profiles of MAP after D157070 treatment for up to 3 days compared to untreated controls resulted in 63 differentially expressed genes (Bull et al., 2009). What was most interesting about this gene set is that 36 were arranged in adjacent clusters or putative operons. One of these clusters (MAP4201 to MAP4211) contained eleven genes, all showing increased transcription in response to D157070 exposure. Furthermore, of the 8 putative operons showing increased transcription, 3 of these may be regulated by the SigL transcription factor (Bull et al., 2009).

Like all living organisms, iron acquisition is critical, but this is especially true for MAP. As mentioned above, a phenotypic hallmark that defines MAP is the requirement for mycobactin $\mathrm{J}$ in the culture media. Without the presence of this siderophore, MAP cannot grow. In the presence of iron, the MAP transcriptional regulator IdeR binds to a $19 \mathrm{bp}$ consensus promoter sequence called the iron box and represses transcription of genes involved in iron acquisition (Janagama et al., 2009). The MAP oligo array was used to identify genes under the control of IdeR. The $m b t A$ was downregulated whereas $b f r A$ (iron storage gene) was upregulated in iron-rich laboratory media. In addition, $m b t E$ was upregulated in human macrophages, which is a low iron environment. These data demonstrate that MAP does regulate these genes in an iron-dependent fashion.

Other data have recently demonstrated that MAP increases transcription of mycobactin ( $m b t)$ synthesis genes (MAP2169c-MAP2178) inside bovine macrophages (Zhu et al., 2008). This iron exochelin is not required by 


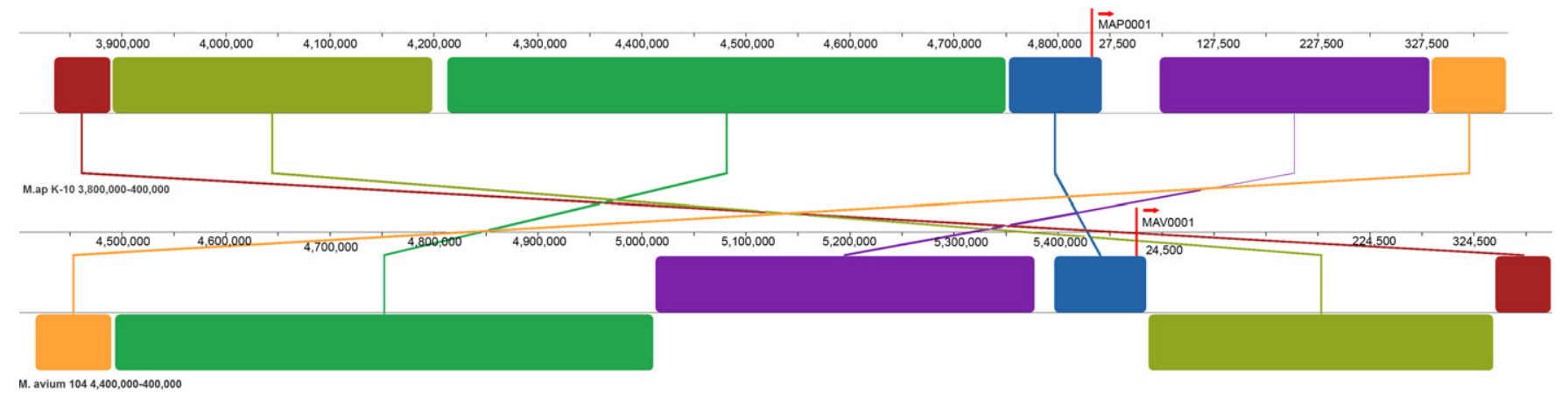

Fig. 2. Extensive genomic rearrangement among MAC species. Genomic inversions between $M A P \mathrm{~K}-10$ and $M A H 104$ were visualized by aligning the two genome sequences with a multiple genome alignment software, Mauve 2.3 (Darling et al. 2004). Upper panel shows the genome segment of MAP K-10, from coordinate 3,800,000, spanning the origin of replicatio

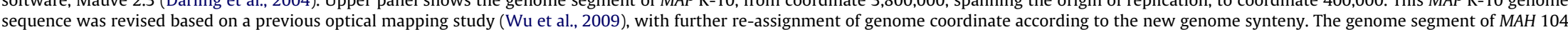

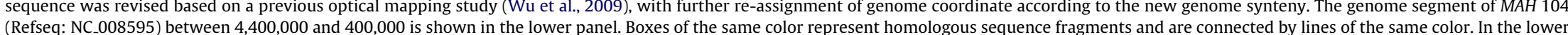

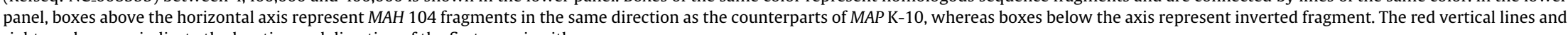
rightward arrows indicate the location and direction of the first gene in either genome. 


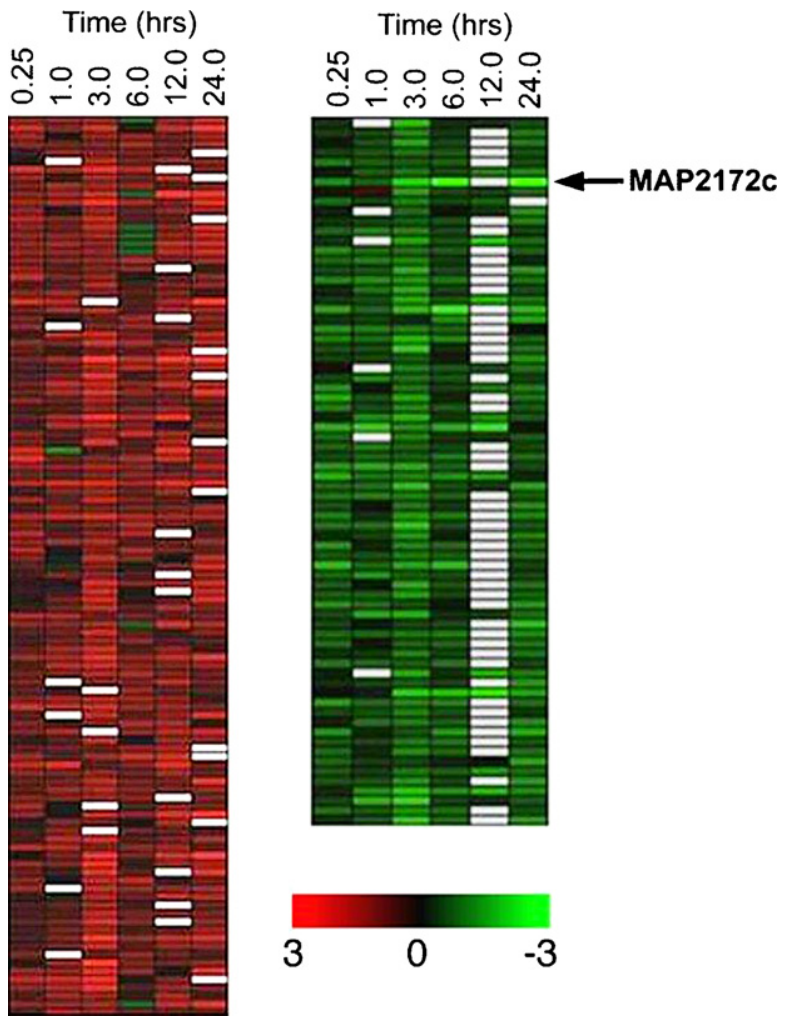

Fig. 3. Differential transcription of MAP genes without mycobactin J in the growth media. Shown are two hierarchical clustered plots, one showing 109 genes with increased transcriptional levels (indicated by red color) in response to the absence of mycobactin J and 72 genes with lower transcriptional activity (green color). The time points when samples were taken for RNA extraction are indicated above each plot and indicate the time exposed to media without mycobactin J. MAP2172c, a gene in the middle of the mycobactin biosynthesis operon, is indicated in the right margin. It shows a steady decrease in transcription with time. (For interpretation of the references to colour in this figure legend, the reader is referred to the web version of the article.)

other members of the MAC group or other species in the genus. We examined the transcriptional profiles of MAP exposed to Middlebrook 7H9 media with and without mycobactin J for $0.5,1,3,6,12$, and $24 \mathrm{~h}$. A total of 109 genes were transcribed at higher levels in the absence of mycobactin J while 72 genes showed reduced transcription (Fig. 3). Although most of the mbt genes were not significantly altered in their expression level, MAP2172c clearly showed decreasing levels of transcription as time in media without mycobactin J lengthened (Fig. 3).

Another publication represents the only study to look at the MAP transcriptome during interaction with host cells. These investigators examined MAP invasion of bovine epithelial cells after the bacteria were inside mammary epithelial cells (MAC-T) or exposed to milk (Patel et al., 2006). This is an important question because transmission of the bacteria is known to occur when calves nurse from an infected dam. These results showed that there was a significant increase in invasion of epithelial cells after MAP was inside MAC-T cells for 24-h and after incubation with milk. Thus the hypothesis is that mammary epithelial cells prime MAP for invasion of intestinal epithelial cells, which is thought to be the initial event in Johne's disease. This observation prompted an examination of which genes are upregulated in MAC-T cells. RNA was extracted from MAPinfected MAC-T cells at the 24-h time point, converted to cDNA, and hybridized to the MAP oligo array. There were 20 genes expressed at a three-fold higher level than the control (Patel et al., 2006). These genes included virulence factors as well as a gene (MAP2751) present uniquely in $M A P$, but has no known function (Bannantine et al., 2004).

\section{Host response to $M$. avium subsp. paratuberculosis infection}

Transcriptomic studies on the host side in response to exposure to MAP are farther along in terms of publications. This may be due to the wider availability of arrays through commercial vendors or greater interest in host response versus pathogen response. The sequencing of the bovine genome and other animal hosts has also helped advance studies in this area (Elsik et al., 2009). The transcriptional response to MAP infection has been explored for many hosts. These include murine (Basler et al., 2008) and bovine (Murphy et al., 2006) macrophages where MAA and MAP infections were directly compared. Human macrophages infected with MAP strains of diverse genotypes have also been studied (Motiwala et al., 2006). The expression profile of MAP infected sheep tissues (Smeed et al., 2009) and bovine illeal tissue (Aho et al., 2003) as well as PBMCs (Coussens et al., 2005, 2004b) has also been performed. Transcriptome analysis on bovine PBMCs showed that MAP infected cells are pro-apoptotic; however, very recent data using FACS sorting to capture only infected cells indicates that the opposite may be true (Coussens, unpublished).

The pro-inflammatory defense mechanisms of infected murine macrophages are suppressed during infection with MAP but not MAA or MAH (Basler et al., 2008). An Affymetrix GeneChip ${ }^{\circledR}$ array that contains 22,690 murine transcripts showed pro-inflammatory factors that include lipocalin, TNF- $\alpha$, IL- $1 \alpha$ and IL- $1 \beta$ were expressed at lower levels in MAP-infected macrophages compared to $M A A$ - or $M A H$-infected macrophages. However, in bovine monocyte-derived macrophages, TNF- $\alpha$ was not upregulated in either MAA or MAP infections and IL-6, a pro-inflammatory cytokine was upregulated (Murphy et al., 2006). In fact, there is an overall suppression of macrophage responses by $M A P$ as compared to $M A A$ (Weiss et al., 2004). These findings suggest that bovine strains of MAP generally modulate the host immune response to prevent inflammation whereas $M A A$ is more of an inflammatory stimulant. Interestingly, the sheep isolates of MAP, regardless of their genotype, differ from the bovine strains in that they induce pro-inflammatory gene expression profiles (Motiwala et al., 2006).

Several studies were completed using bovine peripheral blood mononuclear cells (PBMCs) as the source of the RNA due to the ease of isolation and yield of these cells. Gene expression of bovine PBMCs isolated from cows subclinically or clinical infected has been investigated (Coussens et al., 2002). The PBMCs were incubated with MAP for 16-h and gene expression was determined using the BOTL array. They found 16 genes with increased expression and 11 
genes with decreased expression when comparing subclinical and clinical cattle PBMCs. Greater expression of IFN-Y and IL-10 and decreased expression of IL-1 receptor were among the genes with different expression levels between the two disease states. Another study examined temporal changes in PBMCs from healthy cattle after exposure to MAP for 2, 4, 8 and $16 \mathrm{~h}$ (Coussens et al., 2004a). They saw a decrease in differentially expressed genes as time lengthened, indicating that MAP progressively quenched any macrophage response.

Evaluating gene expression locally in the infected tissues has also been studied. This approach is an improvement because gene expression occurring at the site of infection should give a clearer picture of local host response rather than extracting RNA from circulating PBMCs, which is easier to obtain in large quantities. Expression in ileal tissue from MAP infected cows was compared to uninfected control cows (Aho et al., 2003). IL-1 $\alpha$ was one gene that was significantly overexpressed and it was concluded that overexpression of this gene may be responsible for many of the clinical signs associated with Johne's disease. Recently, the first study to examine gene expression in the ileum of sheep infected with MAP was undertaken (Smeed et al., 2009). The investigators compared asymptomatic sheep with those in the paucibacillary and multibacillary forms of Johne's disease. The cell-mediated immune response that predominates in the paucibacillary form is type $1 \mathrm{CD}^{+}$ $\mathrm{T}$ cells whereas type $2 \mathrm{CD}^{+} \mathrm{T}$ cells direct the multibacillary form, which is the late stage of disease. These disease states in sheep were more completely described recently (Gillan et al., 2010). A total of 596 genes represented on the 4824 spot ruminant immuno-inflammatory gene array (Watkins et al., 2008) revealed 36 genes had a fold change of $\geq 1.5$ and a $P \leq 0.05$. They not only obtained a list of genes differentially expressed in each disease state, but also discovered a genetic susceptibility in the form of a single nucleotide polymorphism (IGFBP6 $\mathrm{G}^{3743}$ ), which is not present in asymptomatic sheep (Smeed et al., 2009).

Thus the general trend observed in these host response experiments is that MAP is efficient at nullifying the macrophage response and prevents $\mathrm{T}$ cell activation. Thus this bacterium is not considered an immune stimulating agent, whereas other members of the MAC group (e.g. MAH) are.

\section{Conclusions}

A lot of work has been completed in this field over the past 2.5-3 years, but much remains to be accomplished. The dominant theme for using microarrays in MAP research appears to be defining genetic diversity and examining the host response to MAP. Because of this focus, researchers now have an excellent understanding of differences in the genomes of MAP isolates and species within the MAC complex. Also, a clearer understanding of how MAP affects the host response is beginning to emerge. In general, MAP infection results in a strangling of the immune response. But more work needs to be performed on the transcriptome of MAP during infection. This area should be a central focus to close the knowledge gap. Another knowledge gap to be close is obtaining the genome sequence of a sheep isolate since genomic and phenotypic differences between bovine and ovine MAP isolates are more evident with each new study.

It will be interesting to see whether new technologies (such as deep sequencing) will take over in place of DNA microarrays in both genomics and transcriptomic studies of MAP. With the increase of complications associated with Johne's disease in cattle and the potential link to Crohn's disease in humans, we urge for more support from USDA and its newly founded authority (NIFA) for research on Johne's disease. Advances achieved so far in the field of $M A P$ genomics and transcriptomics need to be followed by specific gene(s) analyses and discoveries. Such knowledge will be eventually translated to products such vaccines and better control strategies directed towards Johne's disease.

\section{Conflict of interest statement}

The authors have no conflicts.

\section{Acknowledgements}

We wish to acknowledge Mike Paustian, and Chia-wei $\mathrm{Wu}$ for their pioneering work in developing microarrays for $M A H$ and MAP. We thank the USDA - Agricultural Research Service, NRI award 2007-35204-18400 and the USDA CAP project (JDIP, USDA-CSREES-NRI Award No. 200855620-18710) for funding the construction of microarrays reported herein as well as for the genomic hybridization studies.

\section{References}

Abomoelak, B., Hoye, E.A., Chi, J., Marcus, S.A., Laval, F., Bannantine, J.P., Ward, S.K., Daffe, M., Liu, H.D., Talaat, A.M., 2009. mosR, a novel transcriptional regulator of hypoxia and virulence in Mycobacterium tuberculosis. J. Bacteriol. 191, 5941-5952.

Agarwal, N., Woolwine, S.C., Tyagi, S., Bishai, W.R., 2007. Characterization of the Mycobacterium tuberculosis sigma factor SigM by assessment of virulence and identification of SigM-dependent genes. Infect. Immun. $75,452-461$.

Aho, A.D., McNulty, A.M., Coussens, P.M., 2003. Enhanced expression of interleukin-1alpha and tumor necrosis factor receptor-associated protein 1 in ileal tissues of cattle infected with Mycobacterium avium subsp. paratuberculosis. Infect. Immun. 71, 6479-6486.

Akama, T., Suzuki, K., Tanigawa, K., Kawashima, A., Wu, H., Nakata, N. Osana, Y., Sakakibara, Y., Ishii, N., 2009. Whole-genome tiling array analysis of Mycobacterium leprae RNA reveals high expression of pseudogenes and noncoding regions. J. Bacteriol. 191, 3321-3327.

Alexander, D.C., Turenne, C.Y., Behr, M.A., 2009. Insertion and deletion events that define the pathogen Mycobacterium avium subsp. paratuberculosis. J. Bacteriol. 191, 1018-1025.

Amonsin, A., Li, L.L., Zhang, Q., Bannantine, J.P., Motiwala, A.S., Sreevatsan, S., Kapur, V., 2004. Multilocus short sequence repeat sequencing approach for differentiating among Mycobacterium avium subsp. paratuberculosis strains. J. Clin. Microbiol. 42, 1694-1702.

Bannantine, J.P., Hansen, J.K., Paustian, M.L., Amonsin, A., Li, L.L., Stabel, J.R., Kapur, V., 2004. Expression and immunogenicity of proteins encoded by sequences specific to Mycobacterium avium subsp. paratuberculosis. J. Clin. Microbiol. 42, 106-114.

Bannantine, J.P., Zhang, Q., Li, L.L., Kapur, V., 2003. Genomic homogeneity between Mycobacterium avium subsp. avium and Mycobacterium avium subsp. paratuberculosis belies their divergent growth rates. BMC Microbiol. 3, 10.

Basler, T., Geffers, R., Weiss, S., Valentin-Weigand, P., Goethe, R., 2008. Mycobacterium avium subspecies induce differential expression of pro-inflammatory mediators in a murine macrophage model: evidence for enhanced pathogenicity of Mycobacterium avium subspecies paratuberculosis. Immunobiology 213, 879-888. 
Beisiegel, M., Mollenkopf, H.J., Hahnke, K., Koch, M., Dietrich, I., Reece, S.T., Kaufmann, S.H., 2009. Combination of host susceptibility and Mycobacterium tuberculosis virulence define gene expression profile in the host. Eur. J. Immunol. 39, 3369-3384.

Boddinghaus, B., Wolters, J., Heikens, W., Bottger, E.C., 1990. Phylogenetic analysis and identification of different serovars of Mycobacterium intracellulare at the molecular level. FEMS Microbiol. Lett. 58, 197203.

Brazma, A., Hingamp, P., Quackenbush, J., Sherlock, G., Spellman, P., Stoeckert, C., Aach, J., Ansorge, W., Ball, C.A., Causton, H.C., Gaasterland, T., Glenisson, P., Holstege, F.C., Kim, I.F., Markowitz, V., Matese, J.C. Parkinson, H., Robinson, A., Sarkans, U., Schulze-Kremer, S., Stewart, J., Taylor, R., Vilo, J., Vingron, M., 2001. Minimum information about a microarray experiment (MIAME)-toward standards for microarray data. Nat. Genet. 29, 365-371.

Bull, T.J., Linedale, R., Hinds, J., Hermon-Taylor, J., 2009. A rhodanine agent active against non-replicating intracellular Mycobacterium avium subspecies paratuberculosis. Gut Pathog. 1, 25

Bull, T.J., Sidi-Boumedine, K., McMinn, E.J., Stevenson, K., Pickup, R., Hermon-Taylor, J., 2003. Mycobacterial interspersed repetitive units (MIRU) differentiate Mycobacterium avium subspecies paratuberculosis from other species of the Mycobacterium avium complex. Mol. Cell. Probes 17, 157-164.

Castellanos, E., Aranaz, A., Gould, K.A., Linedale, R., Stevenson, K., Alvarez, J., Dominguez, L., de Juan, L., Hinds, J., Bull, T.J., 2009. Discovery of stable and variable differences in the Mycobacterium avium subsp. paratuberculosis type I, II, and III genomes by pan-genome microarray analysis Appl. Environ. Microbiol. 75, 676-686.

Coussens, P.M., Colvin, C.J., Rosa, G.J., Perez Laspiur, J., Elftman, M.D., 2003. Evidence for a novel gene expression program in peripheral blood mononuclear cells from Mycobacterium avium subsp. paratuberculosisinfected cattle. Infect. Immun. 71, 6487-6498.

Coussens, P.M., Colvin, C.J., Wiersma, K., Abouzied, A., Sipkovsky, S., 2002 Gene expression profiling of peripheral blood mononuclear cells from cattle infected with Mycobacterium paratuberculosis. Infect. Immun. 70, 5494-5502.

Coussens, P.M., Jeffers, A., Colvin, C., 2004a. Rapid and transient activation of gene expression in peripheral blood mononuclear cells from Johne's disease positive cows exposed to Mycobacterium paratuberculosis in vitro. Microb. Pathog. 36, 93-108.

Coussens, P.M., Pudrith, C.B., Skovgaard, K., Ren, X., Suchyta, S.P., Stabel J.R., Heegaard, P.M., 2005. Johne's disease in cattle is associated with enhanced expression of genes encoding IL-5, GATA-3, tissue inhibitors of matrix metalloproteinases 1 and 2 , and factors promoting apoptosis in peripheral blood mononuclear cells. Vet. Immunol. Immunopathol. $105,221-234$.

Coussens, P.M., Verman, N., Coussens, M.A., Elftman, M.D., McNulty, A.M. 2004b. Cytokine gene expression in peripheral blood mononuclear cells and tissues of cattle infected with Mycobacterium avium subsp. paratuberculosis: evidence for an inherent proinflammatory gene expression pattern. Infect. Immun. 72, 1409-1422.

Darling, A.C., Mau, B., Blattner, F.R., Perna, N.T., 2004. Mauve: multiple alignment of conserved genomic sequence with rearrangements. Genome Res. 14, 1394-1403.

de Juan, L., Mateos, A., Dominguez, L., Sharp, J.M., Stevenson, K., 2005 Genetic diversity of Mycobacterium avium subspecies paratuberculosis isolates from goats detected by pulsed-field gel electrophoresis. Vet. Microbiol. 106, 249-257.

De Smet, K.A., Hellyer, T.J., Khan, A.W., Brown, I.N., Ivanyi, J., 1996 Genetic and serovar typing of clinical isolates of the Mycobacterium avium-intracellulare complex. Tuber. Lung Dis. 77, 71-76.

Dohmann, K., Strommenger, B., Stevenson, K., de Juan, L., Stratmann, J., Kapur, V., Bull, T.J., Gerlach, G.F., 2003. Characterization of genetic differences between Mycobacterium avium subsp. paratuberculosis type I and type II isolates. J. Clin. Microbiol. 41, 5215-5223.

Elsik, C.G., Tellam, R.L., Worley, K.C., Gibbs, R.A., Muzny, D.M., Weinstock, G.M., Adelson, D.L., Eichler, E.E., Elnitski, L., Guigo, R., Hamernik, D.L., Kappes, S.M., Lewin, H.A., Lynn, D.J., Nicholas, F.W., Reymond, A., Rijnkels, M., Skow, L.C., Zdobnov, E.M., Schook, L., Womack, J., Alioto, T., Antonarakis, S.E., Astashyn, A., Chapple, C.E., Chen, H.C., Chrast, J., Camara, F., Ermolaeva, O., Henrichsen, C.N., Hlavina, W., Kapustin, Y., Kiryutin, B., Kitts, P., Kokocinski, F., Landrum, M., Maglott, D., Pruitt, K. Sapojnikov, V., Searle, S.M., Solovyev, V., Souvorov, A., Ucla, C., Wyss, C., Anzola, J.M., Gerlach, D., Elhaik, E., Graur, D., Reese, J.T., Edgar, R.C., McEwan, J.C., Payne, G.M., Raison, J.M., Junier, T., Kriventseva, E.V., Eyras, E., Plass, M., Donthu, R., Larkin, D.M., Reecy, J., Yang, M.Q. Chen, L., Cheng, Z., Chitko-McKown, C.G., Liu, G.E., Matukumalli, L.K. Song, J., Zhu, B., Bradley, D.G., Brinkman, F.S., Lau, L.P., Whiteside M.D., Walker, A., Wheeler, T.T., Casey, T., German, J.B., Lemay, D.G.,
Maqbool, N.J., Molenaar, A.J., Seo, S., Stothard, P., Baldwin, C.L., Baxter R., Brinkmeyer-Langford, C.L., Brown, W.C., Childers, C.P., Connelley, T., Ellis, S.A., Fritz, K., Glass, E.J., Herzig, C.T., Iivanainen, A., Lahmers, K.K., Bennett, A.K., Dickens, C.M., Gilbert, J.G., Hagen, D.E., Salih, H. Aerts, J., Caetano, A.R., Dalrymple, B., Garcia, J.F., Gill, C.A., Hiendleder, S.G., Memili, E., Spurlock, D., Williams, J.L., Alexander, L., Brownstein, M.J., Guan, L., Holt, R.A., Jones, S.J., Marra, M.A., Moore, R., Moore, S.S. Roberts, A., Taniguchi, M., Waterman, R.C., Chacko, J., Chandrabose, M.M., Cree, A., Dao, M.D., Dinh, H.H., Gabisi, R.A., Hines, S., Hume, J., Jhangiani, S.N., Joshi, V., Kovar, C.L., Lewis, L.R., Liu, Y.S., Lopez, J., Morgan, M.B., Nguyen, N.B., Okwuonu, G.O., Ruiz, S.J., Santibanez, J., Wright, R.A., Buhay, C., Ding, Y., Dugan-Rocha, S., Herdandez, J., Holder, M., Sabo, A., Egan, A., Goodell, J., Wilczek-Boney, K., Fowler, G.R., Hitchens, M.E., Lozado, R.J., Moen, C., Steffen, D., Warren, J.T., Zhang, J., Chiu, R., Schein, J.E., Durbin, K.J., Havlak, P., Jiang, H., Liu, Y., Qin, X., Ren, Y., Shen, Y., Song, H., Bell, S.N., Davis, C., Johnson, A.J., Lee, S., Nazareth, L.V., Patel, B.M., Pu, L.L., Vattathil, S., Williams, R.L., Jr., Curry, S., Hamilton, C., Sodergren, E., Wheeler, D.A., Barris, W., Bennett, G.L., Eggen, A. Green, R.D., Harhay, G.P., Hobbs, M., Jann, O., Keele, J.W., Kent, M.P. Lien, S., McKay, S.D., McWilliam, S., Ratnakumar, A., Schnabel, R.D. Smith, T., Snelling, W.M., Sonstegard, T.S., Stone, R.T., Sugimoto, Y., Takasuga, A., Taylor, J.F., Van Tassell, C.P., Macneil, M.D., Abatepaulo, A.R., Abbey, C.A., Ahola, V., Almeida, I.G., Amadio, A.F., Anatriello, E., Bahadue, S.M., Biase, F.H., Boldt, C.R., Carroll, J.A., Carvalho, W.A., Cervelatti, E.P., Chacko, E., Chapin, J.E., Cheng, Y., Choi, J., Colley, A.J., de Campos, T.A., De Donato, M., Santos, I.K., de Oliveira, C.J., Deobald, H., Devinoy, E., Donohue, K.E., Dovc, P., Eberlein, A., Fitzsimmons, C.J., Franzin, A.M., Garcia, G.R., Genini, S., Gladney, C.J., Grant, J.R., Greaser, M.L., Green, J.A., Hadsell, D.L., Hakimov, H.A., Halgren, R., Harrow, J.L. Hart, E.A., Hastings, N., Hernandez, M., Hu, Z.L., Ingham, A., Iso-Touru, T., Jamis, C., Jensen, K., Kapetis, D., Kerr, T., Khalil, S.S., Khatib, H., Kolbehdari, D., Kumar, C.G., Kumar, D., Leach, R., Lee, J.C., Li, C., Logan, K.M., Malinverni, R., Marques, E., Martin, W.F., Martins, N.F., Maruyama, S.R., Mazza, R., McLean, K.L., Medrano, J.F., Moreno, B.T., More, D.D., Muntean, C.T., Nandakumar, H.P., Nogueira, M.F., Olsaker, I., Pant, S.D., Panzitta, F., Pastor, R.C., Poli, M.A., Poslusny, N., Rachagani, S., Ranganathan, S., Razpet, A., Riggs, P.K., Rincon, G., Rodriguez-Osorio, N. Rodriguez-Zas, S.L., Romero, N.E., Rosenwald, A., Sando, L., Schmutz, S.M., Shen, L., Sherman, L., Southey, B.R., Lutzow, Y.S., Sweedler, J.V., Tammen, I., Telugu, B.P., Urbanski, J.M., Utsunomiya, Y.T., Verschoor, C.P., Waardenberg, A.J., Wang, Z., Ward, R., Weikard, R., Welsh, T.H., Jr., White, S.N., Wilming, L.G., Wunderlich, K.R., Yang, J., Zhao, F.Q., 2009. The genome sequence of taurine cattle: a window to ruminant biology and evolution. Science 324, 522-528.

Feizabadi, M.M., Robertson, I.D., Cousins, D.V., Dawson, D.J., Hampson, D.J., 1997. Use of multilocus enzyme electrophoresis to examine genetic relationships amongst isolates of Mycobacterium intracellulare and related species. Microbiology 143, 1461-1469.

Fontan, P.A., Voskuil, M.I., Gomez, M., Tan, D., Pardini, M., Manganelli, R., Fattorini, L., Schoolnik, G.K., Smith, I., 2009. The Mycobacterium tuberculosis sigma factor sigmaB is required for full response to cell envelope stress and hypoxia in vitro, but it is dispensable for in vivo growth. J. Bacteriol. 191, 5628-5633.

Gillan, S., O'Brien, R., Hughes, A.D., Griffin, J.F., 2010. Identification of immune parameters to differentiate disease states among sheep infected with Mycobacterium avium subsp. paratuberculosis. Clin. Vaccine Immunol. 17, 108-117.

Hines, M.E., 2nd, Stabel, J.R., Sweeney, R.W., Griffin, F., Talaat, A.M., Bakker, D., Benedictus, G., Davis, W.C., de Lisle, G.W., Gardner, I.A., Juste, R.A., Kapur, V., Koets, A., McNair, J., Pruitt, G., Whitlock, R.H., 2007. Experimental challenge models for Johne's disease: a review and proposed international guidelines. Vet. Microbiol. 122, 197-222.

Hurley, S.S., Splitter, G.A., Welch, R.A., 1989. Development of a diagnostic test for Johne's disease using a DNA hybridization probe. J. Clin. Microbiol. 27, 1582-1587.

Janagama, H.K., Senthilkumar, T.M., Bannantine, J.P., Rodriguez, G.M., Smith, I., Paustian, M.L., McGarvey, J.A., Sreevatsan, S., 2009. Identification and functional characterization of the iron-dependent regulator (IdeR) of Mycobacterium avium subsp. paratuberculosis. Microbiology $155,3683-3690$

Kendall, S.L., Withers, M., Soffair, C.N., Moreland, N.J., Gurcha, S., Sidders, B., Frita, R., Ten Bokum, A., Besra, G.S., Lott, J.S., Stoker, N.G., 2007. A highly conserved transcriptional repressor controls a large regulon involved in lipid degradation in Mycobacterium smegmatis and Mycobacterium tuberculosis. Mol. Microbiol. 65, 684-699.

Li, L., Bannantine, J.P., Zhang, Q., Amonsin, A., May, B.J., Alt, D., Banerji, N., Kanjilal, S., Kapur, V., 2005. The complete genome sequence of Mycobacterium avium subspecies paratuberculosis. Proc. Natl. Acad. Sci. U.S.A. 102, 12344-12349. 
Marsh, I.B., Bannantine, J.P., Paustian, M.L., Tizard, M.L., Kapur, V., Whittington, R.J., 2006. Genomic comparison of Mycobacterium avium subsp. paratuberculosis sheep and cattle strains by microarray hybridization. J. Bacteriol. 188, 2290-2293.

McGrath, P.T., Lee, H., Zhang, L., Iniesta, A.A., Hottes, A.K., Tan, M.H., Hillson, N.J., Hu, P., Shapiro, L., McAdams, H.H., 2007. High-throughput identification of transcription start sites, conserved promoter motifs and predicted regulons. Nat. Biotechnol. 25, 584-592.

Micklinghoff, J.C., Breitinger, K.J., Schmidt, M., Geffers, R., Eikmanns, B.J., Bange, F.C., 2009. Role of the transcriptional regulator RamB (Rv0465c) in the control of the glyoxylate cycle in Mycobacterium tuberculosis. J. Bacteriol. 191, 7260-7269.

Motiwala, A.S., Janagama, H.K., Paustian, M.L., Zhu, X., Bannantine, J.P., Kapur, V., Sreevatsan, S., 2006. Comparative transcriptional analysis of human macrophages exposed to animal and human isolates of Mycobacterium avium subspecies paratuberculosis with diverse genotypes. Infect. Immun. 74, 6046-6056.

Murphy, J.T., Sommer, S., Kabara, E.A., Verman, N., Kuelbs, M.A., Saama, P., Halgren, R., Coussens, P.M., 2006. Gene expression profiling of monocyte-derived macrophages following infection with Mycobacterium avium subspecies avium and Mycobacterium avium subspecies paratuberculosis. Physiol. Genomics 28, 67-75.

O'Shea, B., Khare, S., Bliss, K., Klein, P., Ficht, T.A., Adams, L.G., Rice-Ficht, A.C., 2004. Amplified fragment length polymorphism reveals genomic variability among Mycobacterium avium subsp. paratuberculosis isolates. J. Clin. Microbiol. 42, 3600-3606.

Ott, S.L., Wells, S.J., Wagner, B.A., 1999. Herd-level economic losses associated with Johne's disease on US dairy operations. Prev. Vet. Med. 40, 179-192.

Overduin, P., Schouls, L., Roholl, P., van der Zanden, A., Mahmmod, N., Herrewegh, A., van Soolingen, D., 2004. Use of multilocus variablenumber tandem-repeat analysis for typing Mycobacterium avium subsp. paratuberculosis. J. Clin. Microbiol. 42, 5022-5028.

Patel, D., Danelishvili, L., Yamazaki, Y., Alonso, M., Paustian, M.L., Bannantine, J.P., Meunier-Goddik, L., Bermudez, L.E., 2006. The ability of Mycobacterium avium subsp. paratuberculosis to enter bovine epithelial cells is influenced by preexposure to a hyperosmolar environment and intracellular passage in bovine mammary epithelial cells. Infect. Immun. 74, 2849-2855.

Paustian, M.L., Kapur, V., Bannantine, J.P., 2005. Comparative genomic hybridizations reveal genetic regions within the Mycobacterium avium complex that are divergent from Mycobacterium avium subsp. paratuberculosis isolates. J. Bacteriol. 187, 2406-2415.

Paustian, M.L., Zhu, X., Sreevatsan, S., Robbe-Austerman, S., Kapur, V., Bannantine, J.P., 2008. Comparative genomic analysis of Mycobacterium avium subspecies obtained from multiple host species. BMC Genomics $9,135$.

Raizman, E.A., Fetrow, J.P., Wells, S.J., 2009. Loss of income from cows shedding Mycobacterium avium subspecies paratuberculosis prior to calving compared with cows not shedding the organism on two Minnesota dairy farms. J. Dairy Sci. 92, 4929-4936.

Rasmussen, S., Nielsen, H.B., Jarmer, H., 2009. The transcriptionally active regions in the genome of Bacillus subtilis. Mol. Microbiol. 73, 1043-1057.

Rozen, S., Skaletsky, H.J., 2000. Primer3 on the WWW for general users and for biologist programmers. In: Krawetz, S., Misener, S. (Eds.), Bioinformatics Methods and Protocols: Methods in Molecular Biology. Humana Press, Totowa, NJ, pp. 365-386.

Sala, C., Grainger, D.C., Cole, S.T., 2009. Dissecting regulatory networks in host-pathogen interaction using chIP-on-chip technology. Cell Host Microbe 5, 430-437.

Saxegaard, F., Baess, I., Jantzen, E., 1988. Characterization of clinical isolates of Mycobacterium paratuberculosis by DNA-DNA hybridization and cellular fatty acid analysis. APMIS 96, 497-502

Semret, M., Alexander, D.C., Turenne, C.Y., de Haas, P., Overduin, P., van Soolingen, D., Cousins, D., Behr, M.A., 2005. Genomic polymorphisms for Mycobacterium avium subsp. paratuberculosis diagnostics. J. Clin. Microbiol. 43, 3704-3712.

Semret, M., Zhai, G., Mostowy, S., Cleto, C., Alexander, D., Cangelosi, G., Cousins, D., Collins, D.M., van Soolingen, D., Behr, M.A., 2004. Extensive genomic polymorphism within Mycobacterium avium. J. Bacteriol. 186, 6332-6334.

Sheridan, J.M., Bull, T.J., Hermon-Taylor, J., 2003. Use of bioinformatics to predict a function for the GS element in Mycobacterium avium subspecies paratuberculosis. J. Mol. Microbiol. Biotechnol. 5, 57-66.
Skovgaard, K., Grell, S.N., Heegaard, P.M., Jungersen, G., Pudrith, C.B., Coussens, P.M., 2006. Differential expression of genes encoding CD30L and P-selectin in cattle with Johne's disease: progress toward a diagnostic gene expression signature. Vet. Immunol. Immunopathol. 112, 210-224.

Smeed, J.A., Watkins, C.A., Gossner, A.G., Hopkins, J., 2009. Expression profiling reveals differences in immuno-inflammatory gene expression between the two disease forms of sheep paratuberculosis. Vet. Immunol. Immunopathol.

Stratmann, J., Strommenger, B., Goethe, R., Dohmann, K., Gerlach, G.F., Stevenson, K., Li, L.L., Zhang, Q., Kapur, V., Bull, T.J., 2004. A 38-kilobase pathogenicity island specific for Mycobacterium avium subsp. paratuberculosis encodes cell surface proteins expressed in the host. Infect. Immun. 72, 1265-1274.

Talaat, A.M., Ward, S.K., Wu, C.W., Rondon, E., Tavano, C., Bannantine, J.P., Lyons, R., Johnston, S.A., 2007. Mycobacterial bacilli are metabolically active during chronic tuberculosis in murine lungs: insights from genome-wide transcriptional profiling. J. Bacteriol. 189, 42654274.

Thorel, M.F., Huchzermeyer, H.F., Michel, A.L., 2001. Mycobacterium avium and Mycobacterium intracellulare infection in mammals. Rev. Sci. Technol. 20, 204-218.

Tizard, M., Bull, T., Millar, D., Doran, T., Martin, H., Sumar, N., Ford, J., Hermon-Taylor, J., 1998. A low G + C content genetic island in Mycobacterium avium subsp. paratuberculosis and M. avium subsp. silvaticum with homologous genes in Mycobacterium tuberculosis. Microbiology $144,3413-3423$.

Toledo-Arana, A., Dussurget, O., Nikitas, G., Sesto, N., Guet-Revillet, H., Balestrino, D., Loh, E., Gripenland, J., Tiensuu, T., Vaitkevicius, K., Barthelemy, M., Vergassola, M., Nahori, M.A., Soubigou, G., Regnault, B., Coppee, J.Y., Lecuit, M., Johansson, J., Cossart, P., 2009. The Listeria transcriptional landscape from saprophytism to virulence. Nature 459, 950-956

Turenne, C.Y., Collins, D.M., Alexander, D.C., Behr, M.A., 2008. Mycobacterium avium subsp. paratuberculosis and $M$. avium subsp. avium are independently evolved pathogenic clones of a much broader group of M. avium organisms. J. Bacteriol. 190, 2479-2487.

Ward, S.K., Hoye, E.A., Talaat, A.M., 2008. The global responses of Mycobacterium tuberculosis to physiological levels of copper. J. Bacteriol. 190, 2939-2946.

Watkins, C., McKellar, A., Jensen, K., George, A., Jones, D., Sharp, M.J., Stevenson, K., Hopkins, J., 2008. Development and validation of an oligonucleotide microarray for immuno-inflammatory genes of ruminants. Vet. Res. Commun. 32, 647-657.

Weiss, D.., Evanson, O.A., Deng, M., Abrahamsen, M.S., 2004. Sequential patterns of gene expression by bovine monocyte-derived macrophages associated with ingestion of mycobacterial organisms. Microb. Pathog. 37, 215-224.

Williams, D.L., Slayden, R.A., Amin, A., Martinez, A.N., Pittman, T.L., Mira, A., Mitra, A., Nagaraja, V., Morrison, N.E., Moraes, M., Gillis, T.P., 2009. Implications of high level pseudogene transcription in Mycobacterium leprae. BMC Genomics 10, 397.

Wu, C.W., Glasner, J., Collins, M., Naser, S., Talaat, A.M., 2006. Wholegenome plasticity among Mycobacterium avium subspecies: insights from comparative genomic hybridizations. J. Bacteriol. 188, 711723.

Wu, C.W., Schmoller, S.K., Shin, S.J., Talaat, A.M., 2007. Defining the stressome of Mycobacterium avium subsp. paratuberculosis in vitro and in naturally infected cows. J. Bacteriol. 189, 7877-7886.

Wu, C.W., Schramm, T.M., Zhou, S., Schwartz, D.C., Talaat, A.M., 2009. Optical mapping of the Mycobacterium avium subspecies paratuberculosis genome. BMC Genomics 10, 25.

Yoshimura, H.H., Graham, D.Y., 1988. Nucleic acid hybridization studies of mycobactin-dependent mycobacteria. J. Clin. Microbiol. 26 , 1309-1312.

Zhong, L., Di Fiore, L., Taylor, D., Begg, D., de Silva, K., Whittington, R.J., 2009. Identification of differentially expressed genes in ileum, intestinal lymph node and peripheral blood mononuclear cells of sheep infected with Mycobacterium avium subsp. paratuberculosis using differential display polymerase chain reaction. Vet. Immunol. Immunopathol. 131, 177-189.

Zhu, X., Tu, Z.J., Coussens, P.M., Kapur, V., Janagama, H., Naser, S., Sreevatsan, S., 2008. Transcriptional analysis of diverse strains Mycobacterium avium subspecies paratuberculosis in primary bovine monocyte derived macrophages. Microbes Infect. 10, 1274-1282. 